\title{
Characterization of obestatin in rat and human stomach and plasma, and its lack of acute effect on feeding behavior in rodents
}

\author{
Muhtashan S Mondal*, Koji Toshinai*, Hiroaki Ueno, Keiichi Koshinaka and Masamitsu Nakazato \\ Division of Neurology, Respirology, Endocrinology, and Metabolism, Department of Internal Medicine, Faculty of Medicine, University of Miyazaki, Kiyotake, \\ Miyazaki 889-1692, Japan \\ (Correspondence should be addressed to M Nakazato; Email: nakazato@med.miyazaki-u.ac.jp) \\ *(M S Mondal and K Toshinai contributed equally to this work)
}

\begin{abstract}
Obestatin is a 23 -amino acid peptide, initially isolated from rat stomach as an endogenous ligand for the orphan G-proteincoupled receptor. Obestatin is derived from proteolytic cleavage of a 117-amino acid precursor, preproghrelin. Ghrelin increases food intake, body weight, and gastric emptying, whereas obestatin has the opposite effects. In this study, we characterized obestatin in both rat and human stomach, and investigated the peptide's effect on feeding behavior. Using reversed-phase high-performance liquid chromatography coupled with RIAs specific for rat and human obestatin, we detected a very small amount of obestatin, compared with ghrelin, in the gastric fundi. The ratios of obestatin to ghrelin
\end{abstract}

are 0.0039 and $1.94 \%$ respectively in the rat and human gastric fundi. In humans, plasma obestatin accounted for $5 \cdot 21 \%$ of the ghrelin concentration, whereas it was undetectable in rat plasma. Plasma ghrelin concentration decreased after a meal in normal subjects, whereas obestatin concentration did not change. When administered centrally or peripherally, obestatin did not suppress food intake in either free-feeding or fasted rodents. Administration of obestatin did not antagonize ghrelin-induced feeding. These findings indicate that obestatin is present at very low levels compared with ghrelin in both rat and human, and has no acute effect on feeding behavior.

Journal of Endocrinology (2008) 198, 339-346

\section{Introduction}

Ghrelin, a 28-amino acid peptide with an n-octanoyl modification, was originally discovered in human and rat stomach as an endogenous ligand for the growth hormone secretagogue receptor (GHS-R; Kojima et al. 1999). Ghrelin is derived from amino residues 24-51 of its 117-amino acid precursor, preproghrelin. Ghrelin is predominantly synthesized in X/A-like cells of the gastric body and consists of two major molecular forms, acylated ghrelin (ghrelin) and des-n-octanoyl ghrelin (des-acyl ghrelin; Date et al. 2000, Hosoda et al. 2000). When administered either centrally or peripherally, ghrelin stimulates GH secretion and food intake (Kojima et al. 1999, Tschöp et al. 2000, Wren et al. 2000, Nakazato et al. 2001). In addition, ghrelin downregulates energy expenditure and conserves body fat; it also increases body weight gain, adipogenesis, and gastric emptying (Nakazato et al. 2001, Tschöp et al. 2001, Tack et al. 2005). Circulating ghrelin in humans and rodents increases before meals and decreases after meals, suggesting a possible role in meal initiation (Cummings et al. 2001).

A comprehensive evaluation of the amino acid sequences of preproghrelin in 11 mammalian species identified a novel conserved peptide, named obestatin (Zhang et al. 2005). Obestatin, a 23-amino acid peptide with C-terminal amidation, was isolated from the rat stomach as a possible endogenous ligand for an orphan G-protein-coupled receptor, GPR39, that belongs to the GHS-R family. GPR39 is expressed in various regions of brain and peripheral tissues in both rats and humans (McKee et al. 1997). Obestatin is derived from amino acid residues 76-98 of rat and human preproghrelin. Obestatin was initially reported to have actions opposite to ghrelin, such as reduction of food intake and body weight, and delaying gastric emptying (Zhang et al. 2005). In addition, obestatin was recently shown to promote pancreatic $\beta$-cell and human islet cell survival and stimulate the expression of main regulatory $\beta$-cell genes in the pancreas (Granata et al. 2008). Several subsequent studies of the actions of obestatin on gut motility and feeding behavior yielded conflicting findings, with some groups reporting positive findings (Bresciani et al. 2006, Carlini et al. 2007) and others reporting negative findings (Gourcerol et al. 2006, Bassil et al. 2007, Gourcerol \& Taché 2007, de Smet et al. 2007). Furthermore, several groups were unable to reproduce the observation that obestatin binds to GPR39 and increases intracellular $\mathrm{Ca}^{2+}$ rise in GPR39-expressing cells (Lauwers et al. 2006, Chartrel et al. 2007, Holst et al. 2007). Taken together, these conflicting data indicate that further experiments are needed to define the role of obestatin in energy homeostasis.

In this study, we first developed two RIAs specific for rat and human obestatin, and characterized obestatin immunoreactive 
molecules in the rat and human stomach by using reversedphase high-performance liquid chromatography (RP-HPLC). We also studied plasma obestatin response to a meal in normal subjects. Using the same experimental designs as used in the original publication, we examined the action of centrally or peripherally administered obestatin on feeding behavior in freely fed and fasted rodents. Finally, we investigated the antagonistic effect of obestatin on ghrelin activity by co-administration of both peptides. Here, we report that the ratio of obestatin to ghrelin in the rat and human stomach is extremely low (0.0038 and $1.94 \%$ respectively) and that obestatin does not affect acute feeding behavior.

\section{Materials and Methods}

\section{Animals}

Male Wistar rats (Charles River Japan, Inc., Shiga, Japan) weighing 300-350 $\mathrm{g}$ and male C57BL/6 mice (Charles River Japan, Inc.) weighing 30-35 g were maintained in individual cages under controlled temperature $\left(21-23^{\circ} \mathrm{C}\right)$ and light (light on 0800-2000 h) with ad libitum access to food and water. Animals were anesthetized by i.p. injections of sodium pentobarbital (Abbott Laboratories), and i.c.v. cannulae were implanted into the lateral cerebral ventricles of rats and mice as previously described (Nakazato et al. 2001). Proper placement of the cannula was verified at the end of the experiments by dye administration. Animals were sham injected before the study, and weighed and handled daily. Only animals that showed progressive weight gain after the surgery were used in subsequent experiments. All experiments were repeated two or three times. All procedures were approved by the University of Miyazaki Animal Care and Use Committee and were in accordance with the Japanese Physiological Society's guidelines for animal care.

\section{Peptides}

Rat and human obestatin, human cocaine and amphetamineregulated transcript (CART), and rat ghrelin were provided from Peptide Institute, Inc. (Osaka, Japan).

\section{Preparation of antisera}

Rat and human obestatin were conjugated with bovine thyroglobulin by the glutaraldehyde method (Mondal et al. 1999). This method links the carrier molecule to the $\mathrm{N}$-terminus of the peptide, thereby producing an antiserum recognizing the $\mathrm{C}$-terminus portion of the peptide. These conjugated peptides were used as immunogens for the generation of polyclonal antibodies. Antibodies for rat ghrelin were raised as described elsewhere (Hosoda et al. 2000). Antibodies raised against the $\mathrm{N}$ - and C-terminal regions of rat ghrelin recognize the acylated and total ghrelin forms respectively.

\section{$R I A$}

Synthetic rat and human obestatin were radioiodinated by the lactoperoxidase method, and the ${ }^{125}$ I-labeled peptides were purified by RP-HPLC. A diluted sample or standard peptide solution $(100 \mu \mathrm{l})$ was incubated for $24 \mathrm{~h}$ with $100 \mu \mathrm{l}$ antiserum diluent (final dilutions were 1/200 000 for antirat obestatin antiserum and 1/90000 for anti-human obestatin antiserum). Following the addition of tracer solution (16 000 c.p.m. $/ 100 \mu \mathrm{l}$ ), mixtures were incubated for $24 \mathrm{~h}$. The second antibody method was used to separate bound and free ligands. The samples were assayed in duplicate and all procedures were performed at $4{ }^{\circ} \mathrm{C}$. The respective intra- and inter-assay coefficients of variation at $50 \%$ binding for rat obestatin were $2 \cdot 8$ and $3 \cdot 2 \%$ respectively; whereas for human obestatin, they were 3.1 and $3.7 \%$ respectively. Rat obestatin (1 ng) and ${ }^{125} \mathrm{I}$-rat obestatin $(5000$ c.p.m.) were added to the plasma sample extracts and then applied to SepPak C-18 cartridges (Waters, Milword, MA, USA); recoveries were $91.5 \pm 0.3 \%$ (S.E.M.) and $90.7 \pm 0.5 \%$ respectively. The recoveries of human obestatin $(1 \mathrm{ng})$ and ${ }^{125}$ I-human obestatin $(5000$ c.p.m.) were $90 \cdot 2 \pm 0 \cdot 5 \%$ (S.E.M.) and $89 \cdot 5 \pm 0 \cdot 2 \%$ respectively. Ghrelin RIA was performed as described elsewhere (Hosoda et al. 2000).

Quantification of obestatin and ghrelin in stomach and plasma

Stomach Rat gastric fundi were obtained from three ad libitum fed adult male Wistar rats. Following anesthesia with sodium pentobarbital, gastric fundi were immediately resected and boiled at $95-100{ }^{\circ} \mathrm{C}$ for $10 \mathrm{~min}$ in a tenfold volume of water to inactivate intrinsic proteases. Human gastric fundi were obtained from three patients who underwent surgery and gave prior written consent. The study was approved by the Ethics Committee for Human Research of University of Miyazaki. After the samples were cooled to $4{ }^{\circ} \mathrm{C}, \mathrm{CH}_{3} \mathrm{COOH}$ and $\mathrm{HCl}$ were added to respective final concentrations of $1 \mathrm{M}$ and $20 \mathrm{mM}$. Stomach tissue was homogenized in a Polytron for $3 \mathrm{~min}$, after which the homogenate was centrifuged at $28000 \boldsymbol{g}$ for $30 \mathrm{~min}$ at $4{ }^{\circ} \mathrm{C}$. Stomach samples were applied to SepPak C-18 cartridges, and peptides were eluted with a $60 \%$ acetronitrile $\left(\mathrm{CH}_{3} \mathrm{CN}\right)$ solution containing $0 \cdot 1 \%$ trifluoroacetic acid (TFA). Portions of each sample, equivalent to $50 \mathrm{mg}$ wet weight, were lyophilized and then subjected to obestatin and ghrelin RIAs. Other portions of eluates were subjected to RP-HPLC under the conditions described in the legend to Fig. 2. All the HPLC fractions were assayed by obestatin RIAs.

Plasma Rat truncal blood ( $n=3,4 \mathrm{ml}$ each) was obtained by decapitation after anesthesia with sodium pentobarbital. Samples were collected into cooled polypropylene tubes containing EDTA.2 NA $(1 \mathrm{mg} / \mathrm{ml}$ blood $)$ and immediately centrifuged. Human blood was collected from 16 normal healthy volunteers. The plasma samples were diluted 1:1 with 
0.9\% saline and applied to SepPak C-18 cartridges preequilibrated with $0.9 \%$ saline. The cartridges were then washed, first with $0.9 \%$ saline, and then with a $10 \% \mathrm{CH}_{3} \mathrm{CN}$ solution containing $0 \cdot 1 \%$ TFA. Adsorbed peptides were eluted with a $60 \% \mathrm{CH}_{3} \mathrm{CN}$ solution containing $0 \cdot 1 \%$ TFA. Some portions of the eluates were subjected to obestatin and ghrelin RIAs. Aliquots of rat plasma eluate were subjected to RP-HPLC and then RIA for rat obestatin.

\section{Meal test}

Healthy volunteers (eight men and eight women; mean age \pm S.E.M., $22 \cdot 2 \pm 2 \cdot 5$ years; body mass index, $19 \cdot 4-24 \cdot 9$, mean \pm S.E.M., $21 \cdot 5 \pm 0 \cdot 6)$ who had fasted overnight were given $450 \mathrm{kcal} / 450 \mathrm{ml}$ liquid meal (RACOL; Otsuka Co., Ltd, Iwate, Japan; $62 \%$ carbohydrate, $20 \%$ fat, and $18 \%$ protein) over $3 \mathrm{~min}$ at $0900 \mathrm{~h}$. Blood was collected at $-5,30,60,90$, 120 , and $180 \mathrm{~min}$ after taking the liquid meal. The Institutional Committee of Faculty of Medicine, University of Miyazaki approved the protocol, and all the subjects provided informed consent before participation. Plasma $(3 \mathrm{ml})$ samples were acidified to prevent degradation of octanolyated ghrelin before application to a SepPak cartridge, and then the plasma concentrations of obestatin and ghrelin were measured by RIAs.

\section{Feeding experiments}

Experiments were performed 1 week after the implantation of i.c.v. cannulae. First, rat obestatin $(0 \cdot 3$ or $3 \mathrm{nmol} / 5 \mu \mathrm{l}$ saline), human obestatin ( $3 \mathrm{nmol} / 5 \mu \mathrm{l}$ saline), or CART ( $1 \mathrm{nmol} / 5 \mu \mathrm{l}$ saline) was administered i.c.v. to rats fed ad libitum $10 \mathrm{~min}$ before the beginning of the dark phase (1950 h), after which 1-, 2-, 4-, and 12-h food intakes were measured ( $n=6$ per group). Secondly, rat obestatin $(0 \cdot 3 \mathrm{nmol} / 2 \mu \mathrm{l}$ saline $)$ or CART $(0 \cdot 3 \mathrm{nmol} / 2 \mu \mathrm{l}$ saline $)$ was administered i.c.v. to mice fed ad libitum at $1950 \mathrm{~h}$, after which 1-, 3-, and 5-h food intakes were measured $(n=7$ per group). Thirdly, rats were fasted overnight for $8 \mathrm{~h}$ and then rat obestatin $(1 \mathrm{nmol} / 5 \mu \mathrm{l}$ saline $)$ or CART $(1 \mathrm{nmol} / 5 \mu \mathrm{l}$ saline $)$ was administered i.c.v. at $1000 \mathrm{~h}$, after which 1- and 2-h food intakes were measured ( $n=6-8$ per group). Fourthly, rat obestatin (125 or $1000 \mathrm{nmol} / \mathrm{kg}$ body weight $/ 50 \mu \mathrm{l}$ saline) was administered i.p. to mice fed ad libitum at $1950 \mathrm{~h}$, after which 1-, 3-, and 5-h food intakes were measured $(n=5$ per group). Fifth, rat ghrelin $(40 \mathrm{nmol} / \mathrm{kg}$ body weight $/ 50 \mu \mathrm{l}$ saline) or rat ghrelin $(40 \mathrm{nmol} / \mathrm{kg}$ body weight) plus rat obestatin (125 nmol/kg body weight) were administered i.p. to mice fed ad libitum at $1000 \mathrm{~h}$, after which 1- and 2-h food intakes were measured ( $n=5$ per group). These feeding tests were performed using a crossover design experiments in which animals were randomized to receive either test substance with a washout period of 3 days between each administration.

\section{Statistical analysis}

All data are expressed as means \pm s.E.M. Groups of data (means \pm s.E.M.) were compared using ANOVA and post hoc Fisher's test. $P$ values less than $0 \cdot 05$ are considered significant.

\section{Results}

\section{Obestatin RIA}

Figure 1 shows the amino acid sequences (upper panel) of rat and human obestatin and (lower panel) the standard RIA curves of rat and human obestatin. Half-maximum inhibition
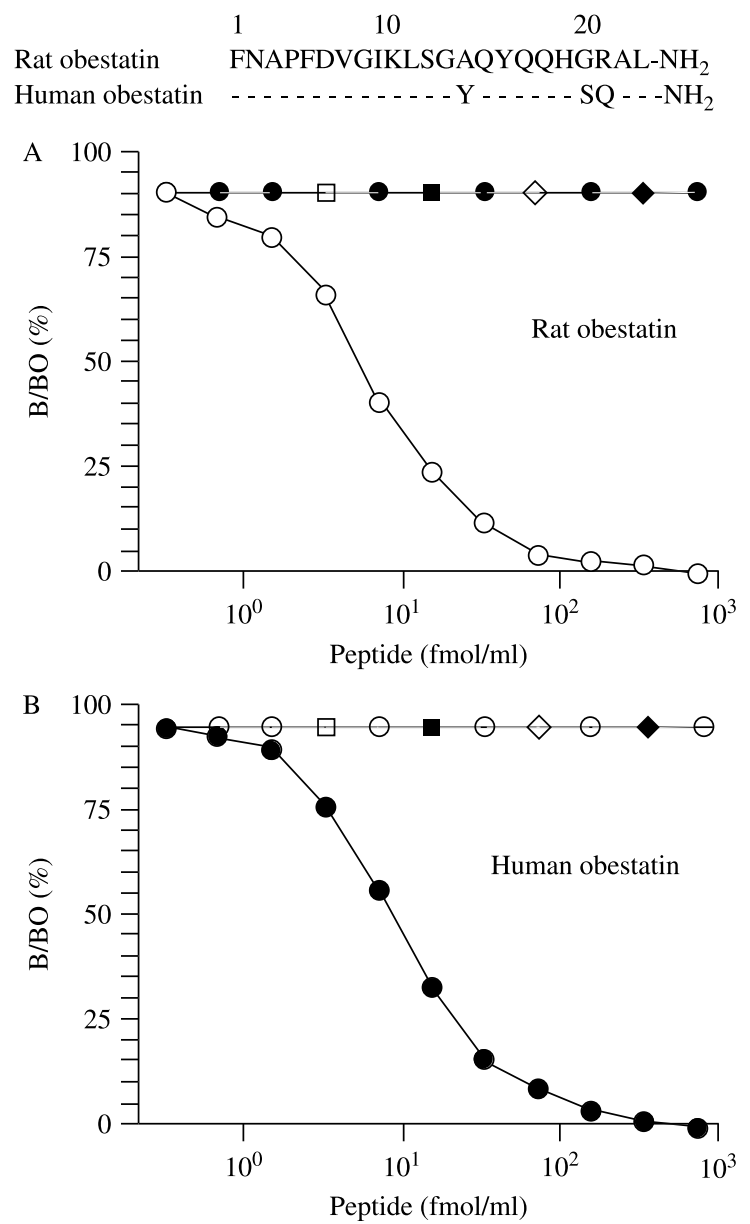

Figure 1 (Upper panel) Alignment of amino acid sequences of rat and human obestatin. Numbers indicate amino acid positions relative to the N-termini. (Lower panel) Standard RIA curves for rat and human obestatin. (A) Inhibition of ${ }^{125}$ I-rat obestatin binding to anti-obestatin antiserum by serial dilution of rat obestatin $(O)$, human obestatin $(\bullet)$, rat ghrelin $(\square)$, human gastrin $(\boldsymbol{\square})$, human gastrin-releasing peptide $(\diamond)$, and human somatostatin $(\diamond)$. (B) Inhibition of ${ }^{125}$ I-human obestatin binding to anti-obestatin antiserum by serial dilution of human obestatin $(\mathbf{0})$, rat obestatin $(\bigcirc)$, rat ghrelin $(\square)$, human gastrin $(\boldsymbol{\square})$, human gastrin-releasing peptide $(\diamond)$, and human somatostatin $(\diamond)$. 

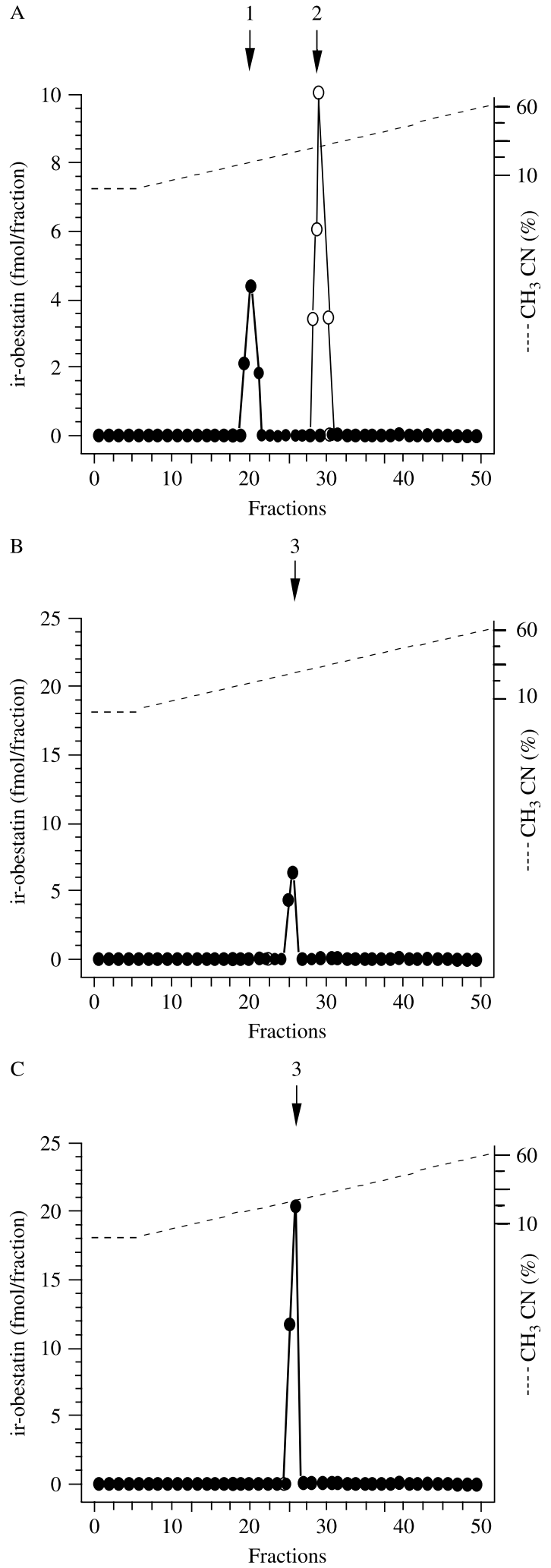

Journal of Endocrinology (2008) 198, 339-346 by rat obestatin was $3 \cdot 2 \mathrm{fmol} / \mathrm{ml}$, and the peptide was detectable at concentrations as low as $0 \cdot 2 \mathrm{fmol} / \mathrm{ml}$ (Fig. 1A). Anti-rat obestatin antiserum recognizes the C-terminal region of rat obestatin, and had no cross-reactivity with human obestatin. Half-maximum inhibition by human obestatin on the standard RIA curve was $7 \cdot 8 \mathrm{fmol} / \mathrm{ml}$, and the peptide was also detectable at the low level of $0 \cdot 2 \mathrm{fmol} / \mathrm{ml}$ (Fig. 1B). Anti-human obestatin antiserum recognizes the C-terminal region of human obestatin and had no crossreactivity with rat obestatin. Neither anti-rat obestatin nor anti-human obestatin antiserum had any cross-reactivity with rat or human ghrelin, human gastrin, human gastrin-releasing peptide, or human somatostatin.

HPLC characterization of ir-obestatin and ghrelin in gastric fundus and plasma

RP-HPLC coupled with obestatin RIAs were used to characterize immunoreactive obestatin molecules in the rat and human gastric fundi and plasma. In the rat gastric fundus, one immunoreactive peak was eluted at the position of synthetic rat obestatin (Fig. 2A) and another immunoreactive peak was detected 4 min later. In both the human gastric fundus and plasma, only one immunoreactive peak was eluted at the position of synthetic human obestatin (Fig. 2B and C).

Obestatin and ghrelin contents in the gastric fundus and plasma

Obestatin contents in the rat and human gastric fundi accounted for 0.0039 and $1.94 \%$ respectively of their ghrelin contents (Table 1). Plasma obestatin concentration in humans accounted for $5 \cdot 21 \%$ of plasma ghrelin concentration. Plasma obestatin was below the detectable value (less than $0 \cdot 2 \mathrm{fmol}$ ) in rats.

\section{Meal test}

The plasma des-acyl ghrelin concentration of normal subjects significantly decreased after taking a test meal, reaching a nadir of $53 \%$ of the basal level $60 \mathrm{~min}$ after meal; obestatin concentration did not change after meal (Fig. 3).

\section{Feeding behavior}

A single i.c.v. administration of rat or human obestatin to rats did not suppress dark-phase food intake (Fig. 4A). Likewise, a single i.c.v. administration of rat obestatin to mice did not

Figure 2 Representative RP-HPLC profiles of obestatin immunoreactivities in (A) rat gastric fundus, (B) human gastric fundus, and (C) human plasma. Sample amounts of rat and human gastric fundi were 1.9 and $1.0 \mathrm{~g}$ wet tissue weight respectively. The sample volume of human plasma was $17 \mathrm{ml}$. Samples were loaded on a TSK ODS SIL 120A column $(4 \cdot 6 \times 150 \mathrm{~mm})$. RP-HPLC was done for $40 \mathrm{~min}$ at $1.0 \mathrm{ml} / \mathrm{min}$ with a linear gradient of $\mathrm{CH}_{3} \mathrm{CN}(10-60 \%)$ in $0 \cdot 1 \%$ TFA. Each fraction was $0.5 \mathrm{~min}$. Arrows indicate the elution positions of 1) rat obestatin, 2) unknown immunoreactive peak, and 3) human obestatin. 
Table 1 Obestatin and ghrelin amounts in rat and human gastric fundi and plasma. Values are mean \pm S.E.M. $(n=3$, human plasma $n=16)$

\begin{tabular}{|c|c|c|c|}
\hline & Obestatin & Ghrelin & $\begin{array}{l}\text { Ratio of obestatin } \\
\text { to ghrelin }(\%)\end{array}$ \\
\hline Rat gastric fundus & $0 \cdot 18 \pm 0.03 \mathrm{fmol} / \mathrm{mg}$ & $4633 \cdot 5 \pm 440 \cdot 1 \mathrm{fmol} / \mathrm{mg}$ & $0 \cdot 0039$ \\
\hline Rat plasma & Not detected & $344 \cdot 4 \pm 40 \cdot 6 \mathrm{fmol} / \mathrm{ml}^{\circ}$ & - \\
\hline Human gastric fundus & $0 \cdot 17 \pm 0 \cdot 02 \mathrm{fmol} / \mathrm{mg}$ & $8.75 \pm 1.90 \mathrm{fmol} / \mathrm{mg}$ & 1.94 \\
\hline Human plasma & $6 \cdot 9 \pm 0.28 \mathrm{fmol} / \mathrm{ml}^{\circ}$ & $132 \cdot 4 \pm 13 \cdot 1 \mathrm{fmol} / \mathrm{ml}$ & $5 \cdot 21$ \\
\hline
\end{tabular}

suppress feeding (Fig. 4B), nor did an i.c.v. administration of rat obestatin suppress feeding in rats that had been fasted overnight (Fig. 4C). In these experiments, CART, which was used as a positive control, significantly suppressed food intake. Next, we studied the effect of peripheral administration of rat obestatin on feeding. A single i.p. administration of 125 or $1000 \mathrm{nmol} / \mathrm{kg}$ rat obestatin to mice did not suppress food intake (Fig. 4D). By contrast, i.p. administration of ghrelin significantly increased food intake in mice, but co-administration of obestatin did not antagonize ghrelin-induced feeding (Fig. 4E). All experiments were done in a crossover format, in which all animals received an injection of obestatin, CART or ghrelin on separate days.

\section{Discussion}

The use of evolutionary genomics screening approach led to the discovery of obestatin (Zhang et al. 2005). The authors identified the presence of obestatin in the rat stomach by peptide sequence analysis. They also reported that central or peripheral administration of obestatin to rats suppressed feeding. We first characterized obestatin immunoreactive molecules in the stomach of rats and humans by two RIAs specific for rat and human obestatin respectively. Both rat and human gastric fundi contain obestatin immunoreactive molecules, but their obestatin contents accounted for as little as 0.0038 and 1.94\% of their ghrelin contents respectively. Zhang et al. (2005) also identified a C-terminal 13-amino acid fragment of obestatin eluted after obestatin itself in their HPLC analyses of rat stomach; consistent with this, our HPLC analysis of rat gastric fundus detected obestatin and another obestatin immunoreactive peak in fractions $27-31$ eluted after obestatin. Rat and human obestatin differ by only three amino acids at positions 14 , 20, and 21 (Fig. 1); however, the rat obestatin antiserum used in this study showed no cross-reactivity with human obestatin, suggesting that this antiserum recognized the C-terminal portion of rat obestatin. The obestatin immunoreactive peptide in fractions 27-31 may be a C-terminal 13-amino acid peptide fragment of obestatin or an $\mathrm{N}$-terminally extended longer form of obestatin. Further sequence determination is needed to identify this unknown obestatin-related peptide.

Obestatin accounted for only $5 \cdot 21 \%$ of ghrelin concentration in the human plasma, but was undetectable in the rat plasma. Obestatin contents in the gastric fundi of rats and humans are nearly equal $(0 \cdot 18 \pm 0 \cdot 03$ and $0 \cdot 17 \pm$ $0.02 \mathrm{fmol} / \mathrm{mg}$ respectively). The ratio of obestatin to ghrelin in the gastric fundi of rats and humans is extremely low $(0 \cdot 0039 \%$ and $1 \cdot 94 \%$ respectively). The presence of very low obestatin content in rat stomach may be due to rapid degradation of obestatin and/or a low processing rate of obestatin from preproghrelin. We therefore speculate may be due to this reason obestatin immunoreactivity was not detectable in the rat plasma. Bioactive peptides are cleaved from precursor proteins via limited cleavage and often undergo post-translational modifications indispensable for their biological activities. Processing of ghrelin after the initial removal of signal peptide involves a single cleavage, whereas the processing of obestatin requires cleavages at both the amino and carboxy termini (Garg 2007). Because the proposed proteolytic sites for cleavage of obestatin from proghrelin lack the more efficient dibasic residues, lysine and arginine, these cleavages might occur with reduced efficiency. In vitro digestion of proghrelin using several convertases fails to generate obestatin (Ozawa et al. 2007). These results suggest that obestatin may be a post-translational by-product of preproghrelin with no relevant physiological bioactivity.

Circulating human ghrelin is suppressed by food intake in humans (Cummings et al. 2001, Shiiya et al. 2002); we therefore compared the plasma obestatin with plasma ghrelin in response to meal in normal subjects. The plasma des-acyl ghrelin concentration significantly decreased after a meal, while the plasma obestatin concentration did not change. Human plasma obestatin concentration did not change even after intake of a $1550 \mathrm{kcal}$ meal (Huda et al. 2008). Thus, obestatin secretion does not appear to be influenced by dietary nutrients.

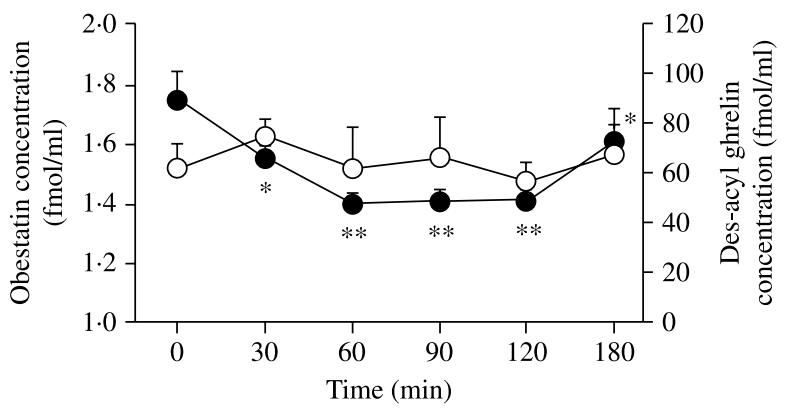

Figure 3 Human plasma obestatin $(\bigcirc)$ and des-acyl ghrelin levels in a meal test in normal subjects. ${ }^{*} P<0 \cdot 05,{ }^{* *} P<0 \cdot 001$ versus des-acyl ghrelin at $0 \mathrm{~min} ; n=16$. 

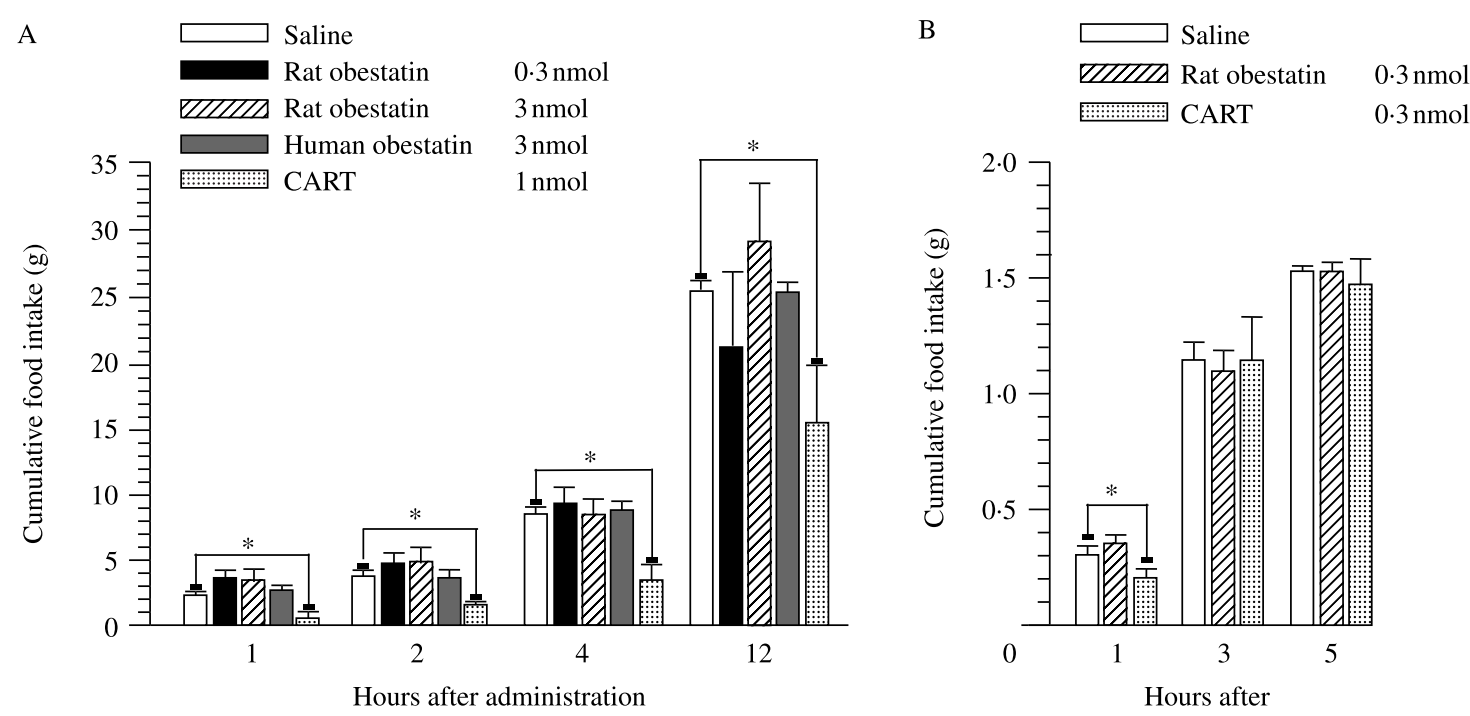

Hours after administration

C
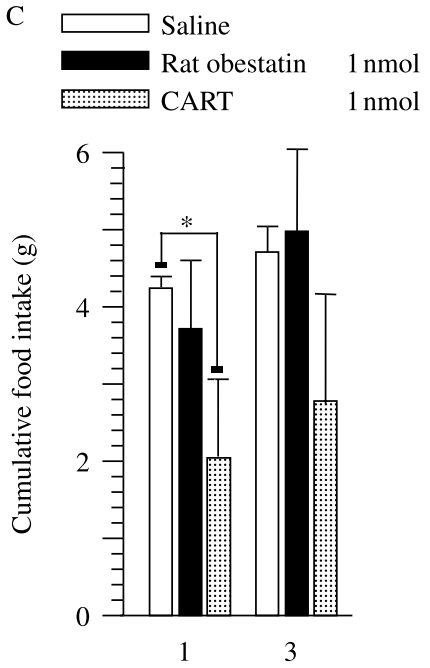

Hours after administration
D

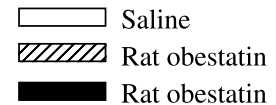

$125 \mathrm{nmol} / \mathrm{kg}$ $1000 \mathrm{nmol} / \mathrm{kg}$

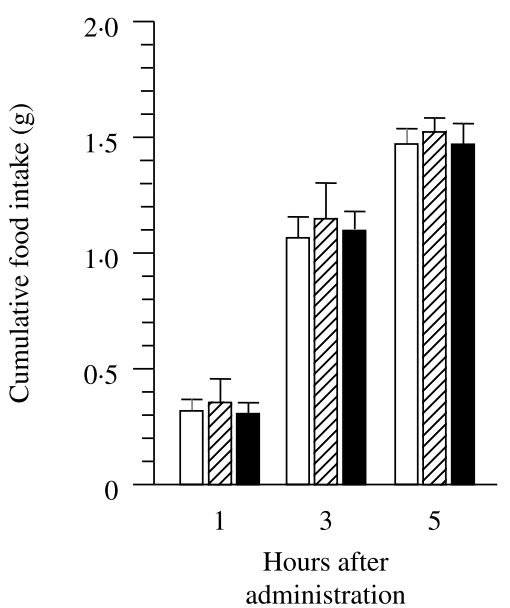

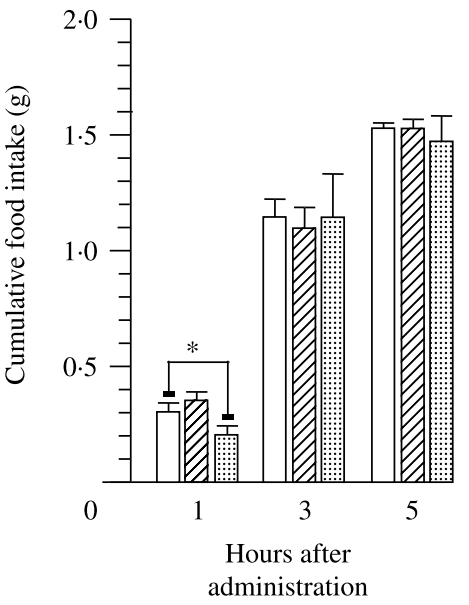

E
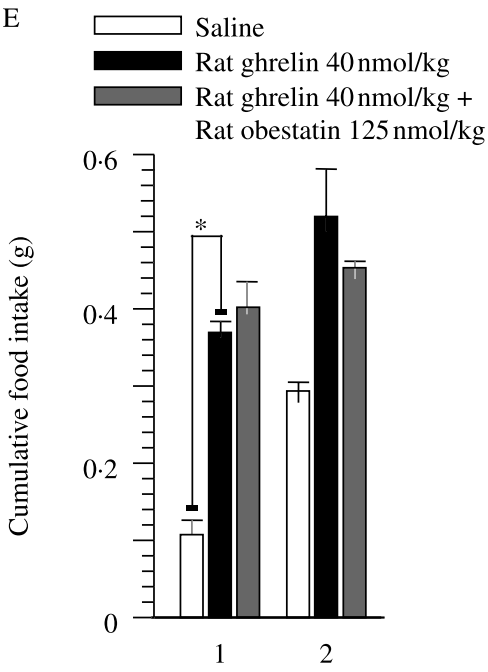

Hours after administration

Figure 4 No effect on central or peripheral administration of obestatin on food intake. (A) Cumulative food intake in free-feeding rats in the dark phase ( $n=6$ per group) following i.c.v. administration of saline, rat obestatin $(0 \cdot 3,3 \cdot 0 \mathrm{nmol})$, human obestatin $(3 \cdot 0 \mathrm{nmol})$, or CART $(1 \mathrm{nmol})$. (B) Cumulative food intake in free-feeding mice in the dark phase ( $n=7$ per group) following i.c.v. administration of saline, rat obestatin $(0.3 \mathrm{nmol})$, or CART $(0.3 \mathrm{nmol})$. (C) Cumulative food intake in fasted rats in the light phase ( $n=6-8$ per group) was measured following i.c.v. administration of saline, rat obestatin $(1 \mathrm{nmol})$, or CART (1 nmol). (D) Cumulative food intake in free-feeding mice in the dark phase ( $n=5$ per group) following i.p. administration of rat obestatin $(125,1000 \mathrm{nmol} / \mathrm{kg})$. (E) Cumulative food intake in free-feeding mice in the light phase ( $n=5$ per group) following i.p. administration of rat ghrelin $(40 \mathrm{nmol} / \mathrm{kg}$ ) or administration of rat ghrelin ( $40 \mathrm{nmol} / \mathrm{kg})$ plus rat obestatin $(125 \mathrm{nmol} / \mathrm{kg}) .{ }^{*} P<0 \cdot 01$ versus saline controls.

The present study showed that a central or peripheral administration of obestatin had no suppressive effects on food intake in either rats or mice fed ad libitum. The administration of obestatin at a very high dose $(1000 \mathrm{nmol} / \mathrm{kg}$, i.p.) did not exert any suppressive effects in mice, in contrast to the original report (Zhang et al. 2005). Similar negative findings using $1000 \mathrm{nmol} / \mathrm{kg}$ obestatin in mice were reported by other groups (Gourcerol et al. 2006, Holst et al. 2007, Nogueiras et al. 2007). The administration of obestatin to fasted rats failed to suppress food intake in this study, also consistent with recent reports (Gourcerol et al. 2006, de Smet et al. 2007). We used a satiety peptide, CART, as a positive control in all our feeding experiments. CART decreased food intake in rats and mice, thus confirming our findings regarding obestatin.

The functional antagonism of obestatin against ghrelin was assessed in this study by co-administration of obestatin and 
ghrelin. In contrast to the original report (Zhang et al. 2005), the administration of obestatin did not antagonize ghrelininduced feeding. Our findings show that obestatin does not function in feeding behavior as a satiety peptide. The hypothalamic arcuate nucleus is critical for feeding regulation, as it contains neuropeptide Y (NPY) and agouti-related protein $(\mathrm{AgRP})$ neurons, whose activation stimulates feeding, and pro-opiomelanocortin (POMC) and CART neurons, whose activation suppresses feeding (Schwartz et al. 2000). Ghrelin administration activated NPY/AgRP neurons, as demonstrated by enhanced c-fos expression on NPY and AGRP neurons and their mRNA expression (Nakazato et al. 2001). Chronic i.c.v. administration of obestatin for 7 days did not change mRNA expression of NPY, AGRP, POMC, or CART (Nogueiras et al. 2007). Taken together, these data suggest that obestatin does not exert any effects on the hypothalamic circuits that control energy balance.

Several groups, including ours, failed to reproduce obestatin's anorexigenic effect upon acute administration (Gourcerol et al. 2006, Bassil et al. 2007, Gourcerol \& Taché 2007, de Smet et al. 2007). Differences in experimental conditions and species used in the original and the subsequent negative reports do not appear to be involved. The administration of obestatin by i.p., s.c., or i.c.v., was equally inefficient to influence food intake (Gourcerol \& Taché 2007, Holst et al. 2007, Nogueiras et al. 2007). Negative findings were even obtained under testing conditions mimicking the initial report, and use of different doses, spontaneous feeding or fasting, and species (rat or mice; Gourcerol \& Taché 2007, Holst et al. 2007, Nogueiras et al. 2007). By contrast, the administration of CART and ghrelin as control peptides in our experiments under similar conditions resulted in either suppression or stimulation of food intake respectively. Investigation of human and rat/mouse obestatin, which share $87 \%$ homology, under nocturnal fasting, 50\% food deprived conditions, and in the darkness and light phases, all resulted in the same negative outcome (Gourcerol \& Taché 2007, Holst et al. 2007, Nogueiras et al. 2007). These findings further confirm that obestatin does not hold its promise so far to regulate food intake in rodents.

In summary, the present study demonstrated that obestatin immunoreactive molecules are present in the rat and human gastric fundi at very low levels compared with ghrelin. In addition, neither central nor peripheral administration of obestatin suppressed food intake in freely fed or fasted rodents, and obestatin did not antagonize ghrelin-induced feeding. Thus, obestatin derived from preproghrelin may not act as a biological active peptide, as initially reported, to regulate acute feeding behavior in rodents.

\section{Declaration of Interest}

The authors declare that there is no conflict of interest that would prejudice the impartiality of this scientific work.

\section{Funding}

This study was supported in part by the 21st Century COE Program and Grants-in-Aid from the Ministry of Education, Culture, Sports, Science, and Technology of Japan; the Ministry of Health, Labor and Welfare of Japan; the Japan Society for the Promotion of Science; Takeda Science Foundation; Foundation for Growth Science; Smoking Research Foundation; Novo Nordisk Growth and Development Study Award; Society of Molecular Mechanism of Digestive Tract; to M N.

\section{References}

Bassil AK, Haglund Y, Brown J, Rudholm T, Hellström PM, Näslund E, Lee K \& Sanger GJ 2007 Little or no ability of obestatin to interact with ghrelin or modify motility in the rat gastrointestinal tract. British Journal of Pharmacology $15058-64$.

Bresciani E, Rapetti D, Donà F, Bulgarelli I, Tamiazzo L, Locatelli V \& Torsello A 2006 Obestatin inhibits feeding but does not modulate GH and corticosterone secretion in the rat. Journal of Endocrinological Investigation 29 $16-18$.

Carlini VP, Schiöth HB \& Debarioglio SR 2007 Obestatin improves memory performance and causes anxiolytic effects in rats. Biochemical and Biophysical Research Communications 352 907-912.

Chartrel N, Alvear-Perez R, Leprince J, Iturrioz X, Reaux-Le Goazigo A, Audinot V, Chomarat P, Coge F, Nosjean O, Rodriguez M et al. 2007 Comment on 'Obestatin, a peptide encoded by the ghrelin gene, opposes ghrelin's effects on food intake'. Science 315766.

Cummings DE, Purnell JQ, Frayo RS, Schmidova K, Wisse BE \& Weigle DS 2001 A preprandial rise in plasma ghrelin levels suggests a role in meal initiation in humans. Diabetes 50 1714-1719.

Date Y, Kojima M, Hosoda H, Sawaguchi A, Mondal MS, Suganuma T, Matsukura S, Kangawa K \& Nakazato M 2000 Ghrelin, a novel growth hormone-releasing acylated peptide, is synthesized in a distinct endocrine cell type in the gastrointestinal tracts of rats and humans. Endocrinology 141 4255-4261.

Garg A 2007 Commentary: the ongoing saga of obestatin: is it a hormone? Journal of Clinical Endocrinology and Metabolism 92 3396-3398.

Gourcerol G \& Taché Y 2007 Obestatin-a ghrelin-associated peptide that does not hold its promise to suppress food intake and motility. Neurogastroenterology and Motility 19 161-165.

Gourcerol G, Million M, Adelson DW, Wang Y, Wang L, Rivier J, St-Pierre DH \& Taché Y 2006 Lack of interaction between peripheral injection of CCK and obestatin in the regulation of gastric satiety signaling in rodents. Peptides 27 2811-2819.

Granata R, Settanni F, Gallo D, Trovato L, Biancone L, Cantaluppi V, Nano R, Annunziata M, Campiglia P, Arnoletti E et al. 2008 Obestatin promotes survival of pancreatic $\beta$-cells and human islets and induces expression of genes involved in the regulation of $\beta$-cell mass and function. Diabetes $\mathbf{5 7}$ 967-979.

Holst B, Egerod KL, Schild E, Vickers SP, Cheetham S, Gerlach LO, Storjohann L, Stidsen CE, Jones R, Beck-Sickinger AG et al. 2007 GPR39 signaling is stimulated by zinc ions but not by obestatin. Endocrinology 148 $13-20$.

Hosoda H, Kojima M, Matsuo H \& Kangawa K 2000 Ghrelin and des-acyl ghrelin: two major forms of rat ghrelin peptide in gastrointestinal tissue. Biochemical and Biophysical Research Communications 279 909-913.

Huda MS, Durham BH, Wong SP, Deepak D, Kerrigan D, McCulloch P, Ranganath L, Pinkney J \& Wilding JP 2008 Plasma obestatin levels are lower in obese and post-gastrectomy subjects, but do not change in response to a meal. International Journal of Obesity 32 129-135.

Kojima M, Hosoda H, Date Y, Nakazato M, Matsuo H \& Kangawa K 1999 Ghrelin is a growth-hormone-releasing acylated peptide from stomach. Nature 402 656-660. 
Lauwers E, Landuyt B, Arckens L, Schoofs L \& Luyten W 2006 Obestatin does not activate orphan G protein-coupled receptor GPR39. Biochemical and Biophysical Research Communications 351 21-25.

McKee KK, Tan CP, Palyha OC, Liu J, Feighner SD, Hreniuk DL, Smith RG, Howard AD \& Van der Ploeg LH 1997 Cloning and characterization of two human G protein-coupled receptors genes (GPR38 and GPR39) related to the growth hormone secretagogue and neurotensin receptors. Genomics $\mathbf{4 6}$ 426-434.

Mondal MS, Nakazato M, Date Y, Murakami N, Yanagisawa M \& Matsukura S 1999 Widespread distribution of orexin in rat brain and its regulation upon fasting. Biochemical and Biophysical Research Communications 256 495-499.

Nakazato M, Murakami N, Date Y, Kojima M, Matsuo H, Kangawa K \& Matsukura S 2001 A role for ghrelin in the central regulation of feeding. Nature 409 194-198.

Nogueiras R, Pfluger P, Tovar S, Arnold M, Mitchell S, Morris A, Perez-Tilve D, Vázquez MJ, Wiedmer P, Castañeda TR et al. 2007 Effects of obestatin on energy balance and growth hormone secretion in rodents. Endocrinology 148 21-26.

Ozawa A, Cai Y \& Lindberg I 2007 Production of bioactive peptides in an in vitro system. Analytical Biochemistry 366 182-189.

Schwartz MW, Woods SC, Porte DJ, Seeley RJ \& Baskin DG 2000 Central nervous system control of food intake. Nature 404 661-671.

Shiiya T, Nakazato M, Mizuta M, Date Y, Mondal MS, Tanaka M, Nozoe S, Hosoda H, Kangawa K \& Matsukura S 2002 Plasma ghrelin levels in lean and obese humans and the effect of glucose on ghrelin secretion. Journal of Clinical Endocrinology and Metabolism 87 240-244. de Smet B, Thijs T, Peeters TL \& Depoortere I 2007 Effect of peripheral obestatin on gastric emptying and intestinal contractility in rodents. Neurogastroenterology and Motility 19 211-217.

Tack J, Depoortere I, Bisschops R, Verbeke K, Janssens J \& Peeters T 2005 Influence of ghrelin on gastric emptying and meal-related symptoms in idiopathic gastroparesis. Alimentary Pharmacology and Therapeutics 22 847-853.

Tschöp M, Smiley DL \& Heiman ML 2000 Ghrelin induces adiposity in rodents. Nature 407 908-913.

Tschöp M, Weyer C, Tataranni PA, Devanarayan V, Ravussin E \& Heiman ML 2001 Circulating ghrelin levels are decreased in human obesity. Diabetes $\mathbf{5 0} 707-709$.

Wren AM, Small CJ, Ward HL, Murphy KG, Dakin CL, Taheri S, Kennedy AR, Roberts GH, Morgan DG, Ghatei MA et al. 2000 The novel hypothalamic peptide ghrelin stimulates food intake and growth hormone secretion. Endocrinology 141 4325-4328.

Zhang JV, Ren PG, Avsian-Kretchmer O, Luo CW, Rauch R, Klein C \& Hsueh AJ 2005 Obestatin, a peptide encoded by the ghrelin gene, opposes ghrelin's effects on food intake. Science 310 996-999.

Received in final form 30 April 2008

Accepted 14 May 2008

Made available online as an Accepted Preprint

14 May 2008 